\title{
Inculturation in the age of virtual reality
}

\author{
A. V. Sakun, T. I. Kadlubovich, D. S. Chernyak \\ Kyiv National University of Technology and Design, Kyiv, Ukraine \\ Corresponding author. E-mail: daryna1804@gmail.com
}

Paper received 17.08.21; Accepted for publication 09.09.21.

\section{https://doi.org/10.31174/SEND-HS2021-258IX47-04}

Annotation. The article analyzes the process of inculturation in the context of reality virtualization. It is noted that inculturation occurs along with the process of socialization, but in post-industrial society it acquires special features, its mechanisms change, its agents become different, which is associated with the technogenic and information diversity of modern culture. The study of the values of student youth is covered, as the system of values is a leading element of culture.

Keywords: inculturation, virtual reality, values, culture.

Introduction. The world has changed, its main component, according to supporters of the information concept of virtual reality, is information. A new type of relationship between culture and society has emerged, when social integration and the formation of personality occur through the processes of awareness, understanding and assimilation of world and national cultures. Inculturation is crucial as a process of forming a person's aesthetic attitude to reality, the ability to perceive the values of culture, the skills of transforming the world through the aestheticization of work, social relations, life and leisure. All this is happening in the era of the domination of virtual reality, when culture is becoming more widespread, and society is influenced by mass and Internet communications, shaping public opinion and the "agenda". "... Postmodern/consumer/deregulated society" causes "incomprehensibility of the life context..., which is "functional" for the state of postmodernity" $[1, p$. 86]. This determines the relevance of studying the process of inculturation in the era of virtual reality, because man "is not only the creator of culture, but also its creation" [3].

Analysis of recent research and publications. Theoretical and methodological analysis of the phenomenon of personality inculturation was to some extent carried out in the works of D. Bell, M. Bakhtin, I. Ilyin, M. Herzkowitz, O. Spengler and others. But the problem of the entry of the individual into culture continues to interest modern philosophers, culturologists, psychologists and educators, encourages them to study various aspects of inculturation. Modern research on the process of inculturation has been carried out by M. Kagan, O. Popovych, T. Smolikova, A. Flier and other scientists, who prove that inculturation is a multifaceted and interdisciplinary problem that requires indepth study. In particular, there are no comprehensive philosophical studies of this problem, not fully identified mechanisms, factors of inculturation, its essence and specificity in a post-industrial society.

Purpose. Analyze the essence of inculturation and its features in the era of virtual reality.

Materials and methods. In the study of the problem of inculturation in the era of virtual reality analysis and systematization of scientific sources, generalization of basic theoretical principles are used. Considering that one of the aspects of inculturation is the formation of a valuable aesthetic attitude to reality, the values of student youth were studied with the help of M. Rokych's method and the corresponding conclusions were made.

Results and discussion. Inculturation should be considered as an integral part of socio-cultural adaptation of the individual, along with socialization, because these processes "coexist, develop simultaneously and are realized in a specific historical form" [6, p. 174]. The socialization of the individual involves the education of "social adequacy to the norms of life, the customs of interaction and the scope of social demands that are optimal for this society" [9, p. 44-45], providing "general knowledge about the world around and involvement in various types of social practice" $[9$, p. 61]. The result of socialization is the inclusion of the individual in a variety of social relationships and role functions [9, p. 61]. The basis of socialization, according to N. Smelzer [7, p.42-43], is the reproduction and transmission of culture to the next generation: If the process of socialization stopped..., it would lead to the destruction of culture" [7, p.43]. Defining culture as a psychological reality, as "the sum of behavior and habitual way of thinking of people who form a certain society" [11, p. 351], M. Herskowitz interprets inculturation as a cultural adaptation of the individual to the dominant, official or normative culture, ie to a set of cultural patterns that are perceived by all members of society in a given historical period. Such cultural patterns for a person are skills, manners, norms of behavior and so on. Inculturation is the submission to stereotypes and procedures accepted in society. This is "the process of human development of the inherent culture of worldview and behavior, resulting in the formation of cognitive, emotional and behavioral similarities with members of this culture and the difference from members of other cultures" [6, p.174]. In other words, inculturation is the acquisition by a person of "cultural competence" through the assimilation of value-semantic attitudes of a certain society [9, p. 44-45], systems of normative-value regulators of social practice, hierarchy of these values, semantic system of their symbolization, norms of their use, use of understanding and interpretation [9, p. 61-62].

If we understand culture as a set of cultural objects, forms, features, meanings, etc., expressed in symbolic form, which "a specialist can "read" as a coherent and conscious text" [9, p. 257], then all cultural phenomena have a semiotic essence and are carriers of certain complexes of information, which is a special kind of reality - information 
reality, one of the aspects of life [2]. In the modern world, information has become the main product of production, and therefore "the whole universe... has become possible to consider as a system of texts, narratives, interpretations, etc." [10]. The world has become virtual because it has become information about itself, one of the ways of existence of which, according to O. Gryaznova [2], is the virtual, which reproduces reality in various forms and finds its expression in simulacra - pseudo-objects that have symbolic significance. ; in simulation - pseudo-actions that symbolically imitate utilitarian functional actions; and the construction of a mythological world in which all internal connections are imitations of the social connections of the human world, and this pseudo-structure itself is described in a small variety of cultural texts. Therefore, the whole culture, according to A. Flier [10], actually built on the principles of virtual reality, allows a person to create their own world with the help of symbols and meanings.

The vast majority of information consumed by modern man are "fantasies and simulacra" [10], produced by art, "unconfirmed media reports, free works of philosophers and writers, household gossip" [10]. In postmodern society, the main sources of cultural knowledge are the latest media, such as television and the Internet, which have unlimited information opportunities: they allow people to travel the world, learn about modern science and technology, provide access to the richest libraries, art galleries, the most interesting museums and exhibitions, thus transporting a person into the world of virtual reality, which is a kind of false representation of reality, because it does not involve the physical presence of man himself.

Flexible mobile technogenic world, which is changing rapidly, gives the process of inculturation features due to the information diversity of modern media culture, which offers a standardized system of images of "social adequacy and prestige", a new form of organization of "cultural competence" [9, p. 389], changes the interests and needs of the individual, values and attitudes to the world. Persistent forms of behavior adopted in a given society, defined as cultural models and including lifestyles and rituals, are also changing. The style involves following certain canons in clothing, housing, forms of communication and more. Rituals are the most formal and stable procedures that are reproduced by people automatically and are a way of identifying a person with a group. This identification also acquires new features and forms. Yes, the era of virtual reality requires a presence in the virtual worlds of Facebook, TikTok, Instagram, etc., which set trends, patterns of consumption, images of prestige and social approval. A person feels involved in one or another virtual group, may refuse real communication and activities. The requirements for cultural samples have also changed. Society has become more tolerant of various cultural and moral differences only socially dangerous behavior is condemned.

Identification is a traditional positive mechanism of inculturation along with imitation. But with the advent of the era of virtual reality, inculturation uses the latest mechanisms. Thus, the Belarusian researcher T. Smolikova [8] determines the mechanisms of implementation of the inculturation process in the virtual and real spaces of the media. She notes that in the age of virtual reality, inculturation takes place in accordance with the specifics of media for- mats. Virtual reality requires the recipient to immerse himself in a single thematic "universe", created by many media formats, provides the opportunity to interact at a distance, changes the geography of communications and more. Therefore, the mechanisms of inculturation are immersion, transmedia, interactivity and mobility. All of them allow to transform forms of communication and thinking, movement and compression of space-time, fast orientation in space, change of kinds of activity (work - game), "inclusion" in on-line conversation, etc. The most complex mechanism of inculturation in the era of virtual reality is visualization - "the mode of existence of the media space" [8], the culture of everyday life, the general principle of which is the "structuring of its artifacts" [8]. Visualization is the birth of a special screen culture.

Stages of inculturation are distinguished similarly to stages of socialization. The primary stage covers childhood and adolescence. The main task of this stage is to master the previous cultural experience, ie the assimilation of cultural norms and traditions. Researchers note that "the first level of inculturation is a mechanism that ensures the stability of culture" [6, p. 174]. It's good when adults who are with a child or teenager at this time help them navigate the whirlpool of information coming from a variety of gadgets. Then we can really talk about the assimilation of cultural norms and traditions. Unfortunately, the situation of a child's "communication" with gadgets and consumption of information is often left unattended. And then we can talk about information chaos, "fascination" of the child with virtual reality, his detachment from real life. The secondary stage of inculturation is characterized by the improvement and acquisition of new skills, knowledge, roles by adults in the process of life, when a person is able to be critical of the world, has a picture of the world and can accept or deny certain cultural phenomena [6, p. 174].

Virtual reality, therefore, affects the process of inculturation, causing changes in the overall cultural and value hierarchy, which determines the way of life and the picture of the world of people, requires systematization, ordering and understanding of new knowledge. In his social activity, a person is mainly guided by the information that comes to him, interpreting it in accordance with their own needs and interests, which, in turn, are the basis of personal values. "Culture contains patterns that help to decide what exists (ideas and concepts about the world around us), what can be (relationships), how to relate to what exists and what can be (values), what to do with it and how to do it (norms)" [7, p.50]. The main of these elements is a system of values - life landmarks that motivate a person or group of people to certain actions; common beliefs about the goal to be pursued and the things (ideas) to be understood.

The study of personal values was conducted in 2020, it involved 55 representatives of student youth of one of the leading higher educational institutions of Ukraine.

Value, as a standard of good behavior, according to D. Leontiev, has three forms of representation: at the level of society, at the level of culture and at the level of the individual. At the level of society, value is a social ideal - a generalized idea of perfection in various spheres of life. At the level of culture, value has a material embodiment in the form of works of material and spiritual culture or human actions and forms of behavior. At the level of the individual, values act as carriers of social regulation. That is why 
values can be considered an indicator of individual inculturation. The system of human values is based on the principle of hierarchy, which reflects the relationship between values of varying degrees of abstraction [4, p. 57], which are terminal and instrumental values. Terminal values act as system-forming for other values. This is the belief of the individual that a certain goal of individual existence is worthy of striving to achieve it. On the basis of terminal values, instrumental values are formed, which, according to $\mathrm{M}$. Rokich, are a reflection of a certain image of actions leading in any situation and necessary and sufficient for the realization of a certain terminal value..

Thus, according to the results of the study of values (according to the method of M. Rokych) it was found that the leading terminal values of student youth were "health" $(66 \%)$, "love" (58\%) and "the presence of good and faithful friends" (58\%), "development" (54\%) and "freedom" (54\%), "self-confidence" (49\%). The leading instrumental values were "independence" (54\%), "honesty" (54\%), "cheerfulness" (51\%) and "education" (47\%).

The obtained results allow to draw a conclusion about a certain level of inculturation of student youth. As we can see, student youth focuses on understanding worldview problems ("freedom"), finding the meaning of life ("development"), gives priority to communication ("love" and "having good and faithful friends") and active life position ("independence", "honesty"). Young people strive for a healthy lifestyle ("health"), perfect human relationships and development. She wants to be independent in her judgments and honest in her thoughts and actions, to have the right to think and act according to her own convictions, to be consciously responsible for her actions, to be confident and free. There is an assumption that such a hierarchy of values is the result of the inculturation of man, characteristic of a society that professes the principles of democracy.

M. Kagan distinguishes several "cultural" types, characteristic of a person who has the freedom to choose a profession, lifestyle, gets the opportunity to be realized. The philosopher gives these types conditional names: "culture of the scholar" when cognitive activity dominates; "culture practice", when the individual is directed to certain forms of practical activities; "moralist culture" - dominated by value-oriented activities; "culture of a sociable person" the emphasis is on establishing friendly relationships with others, which become the basis of all activities; "artist's culture" implies the dominance of artistic activity, creativity, which becomes a "deep need" of man [3]. All these types are the result of culturogenesis, or the process of inculturation. Judging by the results of the study, Ukrainian student youth can be classified as "culture of erudite" and "culture of a sociable person." But it will be interesting to continue research involving students of different specialties and to compare the values of students of technical and artistic specialties.

Висновки. Thus, inculturation can be considered one of the cultural processes, because in its course there is a self-reproduction of cultural systems and forms, intergenerational translation of sociocultural experience, certain norms, standards and rules, translation of a system of images of collective identity in the form of traditions, rites, rituals, normative parameters. lifestyles and worldviews that support the required level of social consolidation of the community, acts of cognition, orientation, interpretation, etc. [9, p. 263].

And although the era of virtual reality gives rise to the massification of culture with its shortcomings, provides a crazy amount of information, not always high quality, the process of inculturation is in accordance with the principles, values and norms professed by a particular society. Ukrainian society sets itself the task of forming a personality that is aware of and realizes the needs for self-education, mastery of the riches of world culture, acceptance of the diversity of the world as multicultural and pluralistic. M. Roerich interpreted culture as a "cult of light", quality in everything, the elevation and illumination of spirituality [5, p. 12], and therefore the process of inculturation has a purpose - to form a person who strives for creativity, overcomes stereotypes, constantly self-improvement and strives for "light". We believe that virtual reality with its features and capabilities will contribute to the heredity and continuation of cultural traditions, the reproduction of the spiritual values of mankind.

\section{LITERATURE}

1. Бауман 3. Индивидуализированное общество / Пер. с англ. под ред. В.Л. Иноземцева. М.: Логос, 2005. 390 с.

2. Грязнова Е.В. Философский анализ концепций виртуальной реальности // Философская мысль. 2013. № 4. С. 53 82. URL: https://nbpublish.com/library_read_article.php?id=278

3. Каган М. С. Философия культуры : учебное пособие для академического бакалавриата. М.: Издательство Юрайт, 2019. 353 c. URL: https://urait.ru/bcode/437807

4. Карпенко 3.С. Аксіологічна психологія особистості. ІваноФранківськ.: Лілея-НВ, 2009. 512 с.

5. Кордон М. В. Українська та зарубіжна культура: Підручник. 3-тє видання. Київ: Центр учбової літератури, 2010. $584 \mathrm{c}$.

6. Попович О. В. Процес соціалізації та процес інкультурації // Вісник Харківського національного педагогічного університету імені Г. С. Сковороди. Філософія. 2016. Вип.

46(2). C. 170-182. URL: http://nbuv.gov.ua/UJRN/VKhnpu_filos_2016_46\%282\%29_19

7.Смелзер Н. Социология: пер. с англ. М.: Феникс, 1994. 688 c.

8. Смоликова Т. М. Инкультурация личности в условиях современного медиапространства Республики Беларусь : автореферат диссертации ... кандидата культурологии : 24.00.01. Минск: [б. и.], 2015. 25 с. URI: http://hdl.handle.net/123456789/6820

9. Флиер А.Я. Культурология для культурологов: Учебное пособие для магистрантов и аспирантов, докторантов и соискателей, а также преподавателей культурологии. М.: Академический Проект, 2000. 496 с.

10. Флиер А.Я. Некультурные функции культуры: Очерки. М.: МГУКИ, 2008. 272 c.

11. Herskovits M. Cultural Anthropology. N.Y.,1955. 


\section{REFERENCES}

1. Bauman Z. Individualized society / Per. s angl. pod red. V.L. Vyp.

$46(2)$

S.

170-182.

URL: Inozemceva. M.: Logos, 2005. $390 \mathrm{~s}$

2. Grjaznova E.V. Philosophical analysis of virtual reality concepts // Philosophical thought. 2013. № 4. S. 53-82. URL: https://nbpublish.com/library_read_article.php?id=278

3. Kagan M. S. Philosophy of Culture: A Textbook for the Academic Undergraduate. M.: Izdatel'stvo Jurajt, 2019. 353 s. URL: https://urait.ru/bcode/437807

4. Karpenko Z.S. Axiological psychology of personality. Ivano-Frankivs'k.: Lileja-NV, 2009. $512 \mathrm{~s}$.

5. Kordon M. V. Ukrainian and foreign culture: Textbook 3tje vydannja. Kyi'v: Centr uchbovoi' literatury, 2010. $584 \mathrm{~s}$.

6 . Popovych O. V. The process of socialization and the process of inculturation // Visnyk Harkivs'kogo nacional'nogo pedagogichnogo universytetu imeni G. S. Skovorody. Filosofija. 2016.

http://nbuv.gov.ua/UJRN/VKhnpu_fi-

los_2016_46\%282\%29_19

7. Smelzer N. Sociology: per. s angl. M.: Feniks, 1994. 688 s.

8. Smolikova T. M. Inculturation of personality in the conditions of modern media space: avtoreferat dissertacii ... kandidata kul'turologii : 24.00.01. Minsk: [b. i.], 2015. 25 s. URI: http://hdl.handle.net/123456789/6820

9. Flier A.Ja. Culturology for culturologists: A textbook for undergraduates and graduate students, doctoral students and applicants, as well as teachers of culturology. M.: Akademicheskij Proekt, 2000. $496 \mathrm{~s}$.

10. Flier A.Ja. Uncultural functions of culture: Essays. M.: MGUKI, 2008. $272 \mathrm{~s}$.

11. Herskovits M. Cultural Anthropology. N.Y.,1955. 